\title{
Olympic Games are likely to be free of Zika cases, say officials
}

\section{Zosia Kmietowicz}

The BMJ

Organisers of the Rio 2016 Olympic Games have said that the chances of anyone becoming infected with the Zika virus during the competition, held in Brazil in August and September, are almost zero.

The numbers of Zika cases in Rio de Janeiro have dropped sharply in recent weeks and will fall to almost nothing during the dry winter months of the Olympic and Paralympic Games, said officials (fig).

Computer modelling conducted in April by Cambridge University Press, UK, showed that only one or two tourists would contract Zika during the games, they said.

João Grangeiro, chief medical officer for Rio 2016, told a press briefing on 7 June, "Zika numbers started declining rapidly in April. The cooler and drier weather will reduce mosquito populations, lowering the risk of mosquito-borne infections."

Officials said that no cases of Zika were reported during 44 test events for the games carried out from August 2014 to May this year, which included 7000 athletes, 8000 volunteers, and 2000 staff. Many of the events took place in Rio's wetter months, when mosquitoes are more prevalent than they will be in the winter months of the games.
The fall in cases of Zika during the drier winter months of the southern hemisphere seems to follow the pattern of dengue fever, where cases tend to peak in the rainy months of March and April and fall to zero from July to September. Both diseases are carried by the Aedes aegypti mosquito.

Olympic officials have promised regular checks at Olympic venues and at athlete accommodation for any stagnant water where mosquitoes tend to breed. Tourists, athletes, and their support teams will also be briefed on how to protect themselves from mosquitoes, they said.

In May a leading public health expert called for the games to be cancelled because of fears of accelerating a global spread of the Zika virus, but the World Health Organization said that travel restrictions were unnecessary. ${ }^{1}$ It advised athletes and visitors to practise safe sex, choose air conditioned accommodation, use insect repellent, and wear light coloured clothing that covers as much of the body as possible.

Coombes R. head of features and investigations. Call to cancel 2016 Olympics because of Zika risk is not backed by WHO guidance. BMJ 2016;353:i2899. doi:10.1136/bmj. i2899 pmid:27207862.

Published by the BMJ Publishing Group Limited. For permission to use (where not already granted under a licence) please go to http://group.bmj.com/group/rights-licensing/ permissions 


\section{Figure}

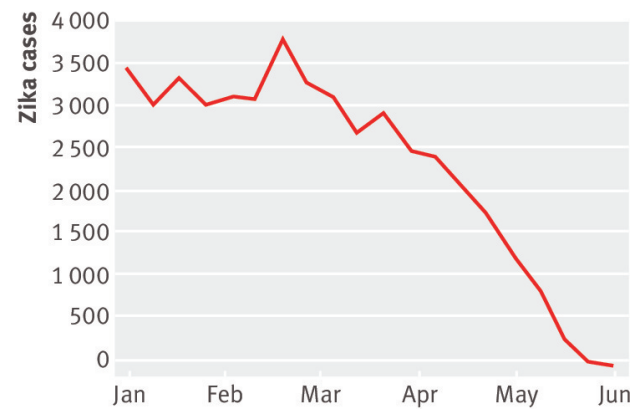

Zika cases in Rio de Janeiro from 1 Jan 2016 to 31 May 2016

[Image: Source: Bulletin of the Secretary of State for Health] 